\title{
Understanding the Biobehavioral and Mental Health Consequences of IPV
}

\author{
Rose Eva Constantino* \\ University of Pittsburgh School of Nursing, Pittsburgh, Pennsylvania 15261, USA
}

\begin{abstract}
Received: September 24, 2015; Accepted: September 25, 2015; Published: November 30, 2015
*Corresponding author: Rose Eva Constantino, University of Pittsburgh, School of Nursing, Victoria Street Suite 415 Pittsburgh, Pennsylvania, USA, Pin:15261; Tel: 412-624-2063; Email : rco100@pitt.edu
\end{abstract}

Intimate Partner Violence (IPV) and its consequences are many. My early legal work representing women in family court as they seek Protection from Abuse (PFA) led me to explore the relationship among negative life experiences, depression and T-cell function in women in IPV. The purpose of the project was to examine differences in the levels of negative life experiences (environmental), depression (sociobehavioral) and immune function (biological) in abused and non-abused women. We learned significant differences with women in abusive relationship reporting more negative life experiences, higher levels of depression, and lower levels T-cell function than non-abused women [1]. Further along my clinical and legal representation of women in IPV relationships, we observed physical (multiple schlerosis), psychosocial and behavioral manifestations of IPV as they relate to abused women [2-4] and collaborated with other researchers in Jordan to evaluate the mental health of Jordanian women in IPV [5].

In our efforts to develop prevention and intervention strategies for women in IPV, we explored the feasibility and efficacy of Email and Mobile delivered intervention in IPV. We subsequently leveraged technology in delivering intervention to a population of women in IPV as disseminated through the following articles: Comparing online with face-to-face HELPP intervention in women experiencing intimate partner violence [6], Exploring the feasibility of text messaging intervention in intimate partner violence [7], Assessing the readability and usability of online H-E-L-P intervention for IPV survivors [8], and Exploring the feasibility of email-mediated interaction in survivors of abuse [6].

Although our experience with randomized trials in IPV-related interventions is not in depth, we have in the past compared two groups of women in IPV to improve IPV-related outcomes [9]. In order to inform interventions as it relates to the well-being and CVD risks of midlife to older women as reported by [10], we developed a theoretical model that integrates the process model of behavior change [11] and the gendered risk factor for CVD [12] in women in IPV. Progressing from conceptual [10] to observational [6] work is important in this area of research because developing intentional, person-centered and well-planned intervention programs such as HELPP delivered in diverse methods (face-to- face, email, text messaging) to women provides opportunities to understand better the complex consequences of IPV on health and evidence-based interventions to disrupt or prevent those health and life- changing consequences of IPV [13,14].

\section{References}

1. Constantino RE, Sekula LK, Rabin B, Stone C. Negative life experiences, depression, and immune function in abused and non-abused women. Biol Res Nurs. 2000;1(3):190-8.

2. Crane PA, Constantino RE. Use of the Interpersonal Support Evaluation List (ISEL) to guide intervention development with women experiencing abuse.Issues Ment Health Nurs. 2003;24(5):523-41.

3. Constantino RE, Sekula, K., Lebish J, Buehner E.Depression and behavioral manifestations of depression in female survivors of the suicide of their significant other and female survivors of abuse. J Am Psychiatr Nurses Assoc. 2002; 8(1):27-32. doi:10.1067/ mpn.2002.122760.

4. 4.0'Leary M,Lammers S, Mageras A, Boyd M, Constantino RE, Heyman R. Relationship between domestic violence and multiple schlerosis. International Journal of MS Care. 2008;10(2):27-32.

5. 5.Hamdan-Mansour AM, Constantino RE, Farrell M, Doswell W, Gallagher ME, Safadi R, Evaluating the mental health of Jordanian women in relationships with intimate partner abuse.Issues Ment Health Nurs. 2011;32(10):614-23. doi: 10.3109/01612840.2011.580494.

6. 6. Constantino, RE, Braxter B, Ren D, Burroughs JD, Doswell W, Wu $\mathrm{L}$, et al. Comparing online with face-to-face HELPP intervention in women experiencing intimate partner violence, Issues Ment Health Nurs. 2015;36(6):430-438. doi: 10.3109/01612840.2014.991049.

7. 7. Constantino RE, Wu L, dela Cruz D, Burroughs J, Hwang JH, Henderson A, et al. Exploring the feasibility of text messaging intervention in intimate partner violence. Open Journal of Nursing.2014;4:528-537. doi: 10.4236/ojn.2014.47056.

8. 8. Constantino RE,Hamdan-Mansour AM, Henderson A, Noll-Nelson B, Doswell W, Braxter B. Assessing the readability and usability of online H-E-L-P intervention for IPV survivors. Open Journal of Nursing. 2014;4:150-157.doi: 10.4236/ojn.2014.43019.

9. 9. Constantino R, Crane PA, Noll BS, Doswell WM, Braxter B. Exploring the feasibility of email-mediated interaction in survivors of abuse.J PsychiatrMent Health Nurs. 2007;14(3):291-301.

10.10. Thurston RC, Chang Y, Derby CA, Bromberger JT, Harlow SD, Janssen I, et al. Abuse and subclinical cardiovascular disease among 
midlife women: The study of women's health across the nation. Stroke. 2014;45(8):2246-51. doi: 10.1161/STROKEAHA.114.005928.

11.11. Greaves C, Gillison F, Stathi A, Bennett P, Reddy P, Dunbar J. Waste the waist: A pilot randomized controlled trial of a primary care based intervention to support lifestyle change in people with high cardiovascular risk. Int J Behav Nutr Phys Act. 2015;12:1. doi: 10.1186/s12966-014-0159-z.

12.12. Scott-Storey KA. Abuse as a gendered risk factor for cardiovascular disease: a conceptual model. J Cardiovasc Nurs. 2013;28(6):E1-8. doi: 10.1097/JCN.0b013e318279e372.
13.13.Constantino R, Kim Y, Crane PA. Effects of a social support intervention on health outcomes in residents of a domestic violence shelter: A pilot study. Issues Ment Health Nurs. 2005;26(6):575-90.

14.14. Constantino, RE,Alameida, AC, Ringold, AH,Klem, ML, WB Greene, Thurston, R Schlenk, E(In Process).Evidence of Subclinical CVD in Women in Intimate Partner Violence: Gendered Risk Behavior and a Process of Behavior Change. 